\title{
CURRENT STATE OF THE FIRST UNESCO GLOBAL GEOPARK: A CASE STUDY OF THE GEOLOGICAL AND MINING PARK OF SARDINIA, ITALY
}

\author{
Adriana MOSSA* \\ University of Seville and University of Sassari, Pabellón de México, \\ Paseo de las Delicias, s/n., 41013 Sevilla (Spain), e-mail: adrianamossa@hotmail.com
}

\author{
José Antonio CAMÚÑEZ-RUIZ \\ University of Seville, Department of Applied Economics I, Avda Ramón y Cajal, \\ 41018 Seville (Spain), e-mail: camunez@us.es \\ Francesco MORANDI \\ University of Sassari, Department of Economic and Business Sciences, \\ Via Muroni 25, 07100 Sassari (Italy), e-mail: morandi@uniss.it
}

\begin{abstract}
Citation: Mossa, A., Camúñez-Ruiz, J. A., \& Morandi F. (2018). CURRENT STATE OF THE FIRST UNESCO GLOBAL GEOPARK: A CASE STUDY OF THE GEOLOGICAL AND MINING PARK OF SARDINIA, ITALY. GeoJournal of Tourism and Geosites. 22(2), 403-418. https://doi.org/10.30892/gtg.22211-298
\end{abstract}

\begin{abstract}
This article deals with the Geological and Mining Park of Sardinia, the first park in the world to be included in the network of Geosites/Geoparks established by UNESCO in 1998. The main purpose of this research paper, given the absence of up-todate official documents, is to map mining sites allocated to tourist use. It also registers the number of visits per year, amount of human resources occupied and methods of management and financing. After a brief description of the birth of tourism in Sardinia and the history of the Park, the findings of a desk and field study within a comparative analysis are presented and evaluated and best management practices highlighted.
\end{abstract}

Key words: Heritage tourism, Geological and Mining Park of Sardinia, industrial mining tourism, Geopark, Geosite

\section{INTRODUCTION}

This research paper is part of a wider study whose final aim is the creation of cultural/tourist paths following the theme of production in Sardinia, from industrial archaeology to business tourism, leading the visitors from the past to the present and linking industrial mining tourism to other sectors such as food and wine and handcraft.

The growth of tourism in Sardinia (Figure 1) in the last sixty years has been considerable and vertiginous. The decisive factors contributing to its development

\footnotetext{
* Corresponding author
} 
include, primarily, the defeat of malaria in the first half of the last century (Tognotti, 2008; Carcassi \& Mura, 2009), secondly, the establishment of the Region with special statutes (Gherardini, 1991; Brigaglia, 2002, p. 38-65; Chessa \& Pinna, 2008), thirdly, the consequent constitution of Ente Sardo Industrie Turistiche (ESIT - Local Board for Tourism Industry) and, finally, the important interventions of foreign capital and the foundation of Consorzio Costa Smeralda by the Saudi Prince Karim Aga Khan II (Roggio, 2002, p. 224-245). Thanks to all these factors, Sardinia has succeeded in establishing itself as an international tourist destination.

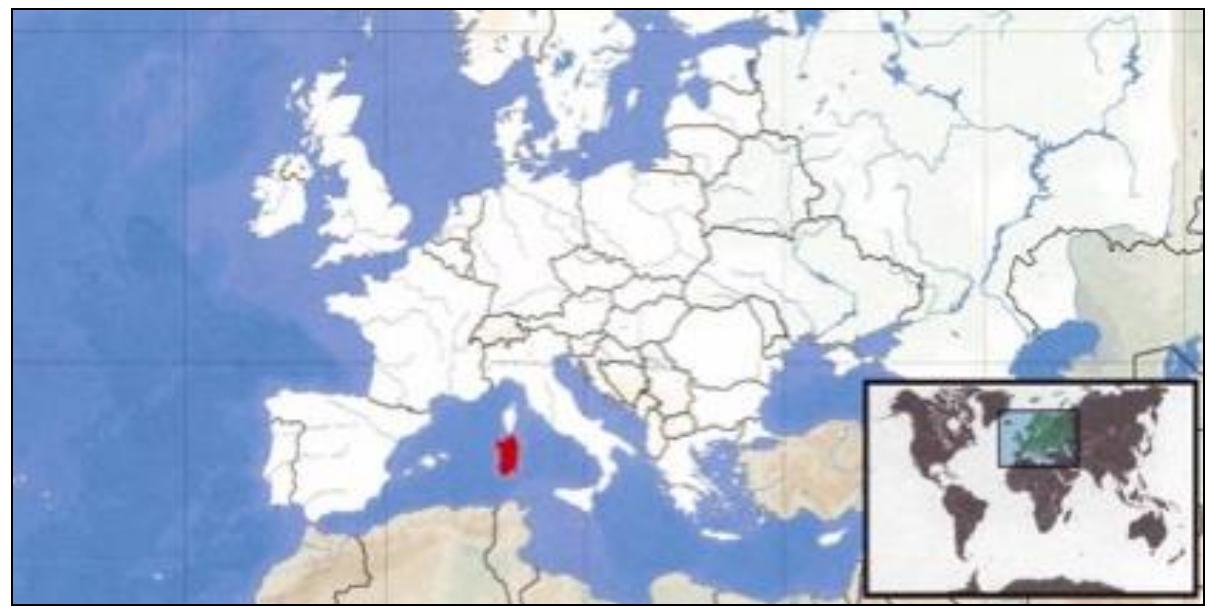

Figue 1. Map of Sardinia in the world

(Source: Geological Mining, Historical and Environmental Park of Sardinia)

The vocation of Sardinia for tourism can be traced back to $1862 / 63$, years leading up to the birth of the first bathing establishments in Alghero and Cagliari. In the forties, the island resort system consisted of 700 hotel rooms, of which only 50 had bathrooms; this was the result of experiments of hotel business in the resorts of Alghero, Bosa, Porto Torres and Cagliari. In 2014 the hotel sector boasted 100,000 beds in the island's 920 hotels, 75\% of which were in the hands of Sardinian entrepreneurs (Ruju, 2014, p. 7-20).

According to official data released in May 2017 by SIRED - the data collection and processing system provided by the Region of Sardinia - 2016 was a record year for tourism with 2.9 million arrivals, 13.5 million occupancies and an average stay of 4.6 days, with an increase of 10.5 percent in arrivals and 9 percent in occupancies. Another significant aspect emerging is the rise in foreign visitors and the growth of arrivals in the off-peak months, spring and autumn (CRENoS, 2017). Surveys conducted in 2013 show that the perceived image of Sardinia is that of a beach resort destination where the sunsea-beach trinomial is the main motivational factor and attraction for those who choose it as a holiday destination. To first time visitors to the island, it appears an interesting, wild and uncontaminated site that fascinates them (Battino, 2013, p. 56).

Sardinia, however, is not just sea, it is also an ancient land that has much to offer to visitors (Castagna, 2008; Lavazza, 2008). Culture, for instance, understood as a hypernym for many tourist segments, offers different opportunities for development. The report Io sono Cultura - 2016 (Unioncamere and Fondazione Symbola, 2016), describes in details the value of culture in Italy, one of the primary factors of the economy and to benefit greatly from its push is especially tourism; in fact more than one third (37.5\%) of 
spending on national tourism is activated by the culture itself. This same topic also recurs in the annual report by Federculture, the national association of public and private bodies, institutions and companies operating in the field of cultural policies and activities (Federculture, 2017). As is known, for tourist areas highly characterized as beach destinations, it is important to emphasize their cultural and social identities, which we can refer to as identity tourism (Fadda, 2001, p. 10). This fact is highlighted by a recent study (Centro Studi Mezzogiorno, 2016), which groups all themes that can be developed or strengthened to mitigate seasonality in Sardinia, such as cinetourism, sport and cultural events, congress tourism, sport tourism (golf and cyclotourism), cruising, wellness and food and wine tourism (Di Gregorio et al., 2014). Regional policies have been put in place (Dettori, 2002, p. 246-264) to tackle the problem of seasonality, which has always been an obstacle to the full development of the tourist sector of the island (Cannas, 2010), and to help the flourishing of various forms of tourism towards rejuvenation in order to escape the notorious decline, as described by the theory of the life cycle of the tourism area (Butler, 2011). Hospers (2003, p. 636) emphasizes the growing interest in cultural and natural heritage, for an authentic Sardinia, which he calls 'real Sardinia', an interest which also affects the industrial heritage. The search for original experiences by tourists offers the opportunity to take advantage of all landscapes understood as cultural landscapes ${ }^{1}$, testaments of various sectors of human production.

Historically in Sardinia the exploitation of mineral resources played a key role and the collection of obsidian (Figure 2) dates back to the 6th millennium $\mathrm{BC}$ in the prehistoric mining district of Monte Arci, (Mezzolani \& Simoncini, 2001).

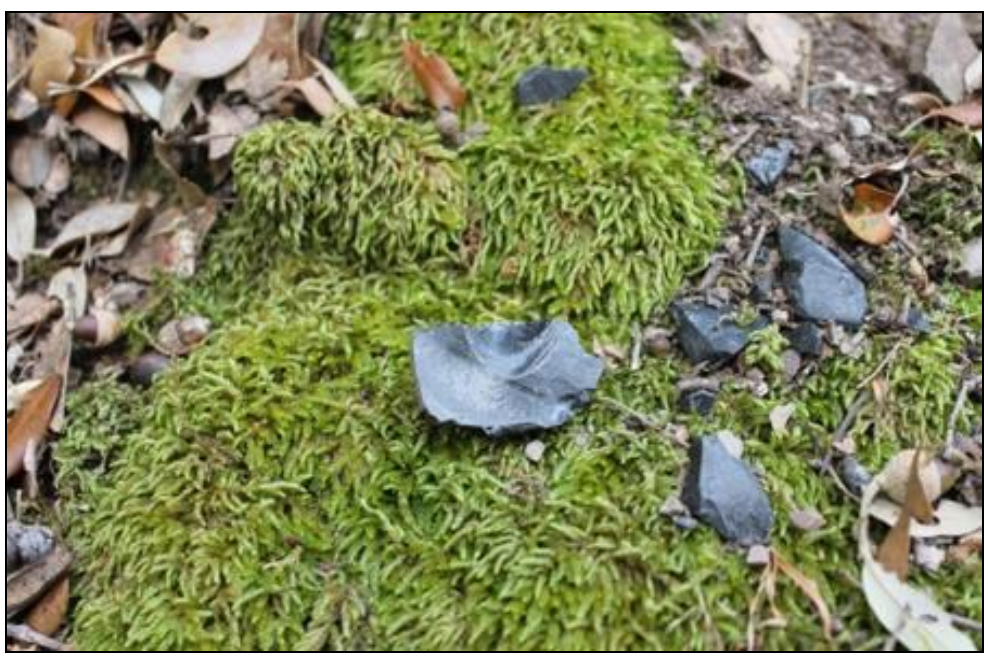

Figure 2. Obsidian on the Sentiero Sennixeddu, in the area of Pau's Museo dell'Ossidiana

All of these places - that have seen the ancient Sardinians as protagonists of economic, social and cultural changes (Olita, 2007; Associazione Minatori e Memoria, 2008) - represent real opportunities to be pursued for a wider and more effective development of tourism and culture in general. In this context the creation of a park in

\footnotetext{
${ }^{1}$ Here we refer to the definition of 'landscape' proposed by the European Landscape Convention (Cartei, 2007), which conceives landscape based on people's perceptions, natural, rural, urban and periurban spaces that embrace not only exceptional landscapes, but also those of everyday life and degraded ones.
} 
Sardinia represented an excellent opportunity, given the influence of the parks in the economic development of a territory (Forleo et al., 2017, p. 231-233).

Finally, the concordant awareness shared by Sardinian public and private sectors of the historic-cultural, archaeological-industrial heritage value of the mines led to the birth of the Geological and Mining Park of Sardinia (Fadda, 2003).

\section{BIRTH OF THE GEOLOGICAL AND MINING PARK OF SARDINIA}

The birth of the Geological and Mining Park of Sardinia is the result of a long journey whose embryonic seed can be traced back to the ideas that emerged during a conference held in Iglesias in 1983 dedicated to mining industrial archaeology (Castelli \& Pintus, 2005, p. 7-15). It was here, in fact, that the participants began to speak of an industrial archaeology park, mineral park and exploitation for tourism purposes and that significant proposals emerged regarding the preservation, conversion and reuse of abandoned industrial facilities. On May 1 1987, Legambiente and the Unions held a large public demonstration at the abandoned mining village of Arenas in Fluminimaggiore. Public consensus led to the creation of a cultural program and two years later a small group of people gathered in Iglesias calling themselves Comitato promotore del Parco (Organizing Committee of the Park), later becoming Associazione per il Parco Geominerario, Ambientale e Storico dell'Iglesiente, Sulcis-Guspinese (Association for the Environmental and Historical Geo-Mining Park, of Iglesiente, Sulcis-Guspinese).

In 1997, the Ente Minerario Sardo (EMSA - Sardinian Mining Authority) invited UNESCO officials to visit the mining areas and one suggested submitting a proposal, with a dossier of information and statement of purpose, to the General Assembly of the Organization of the United Nations to be held in Paris in November of that year. The Dossier gained attention and got full recognition for its universal and cultural values, so much so that, that very day witnessed the establishment of a global network of Geosites/Geoparks with the direct incorporation of the Geological and Mining Park of Sardinia (from this point onwards Park). Thus it became the first geo-mining park in the world and its area extended to all historic mining areas of Sardinia. Since then Geoparks have prospered and Geotourism constitutes a growing market segment with a prosperous future (Farsani et al., 2011; Poch \& Llordés, 2011; Yolal, 2012); at present in the network there are 127 UNESCO Global Geoparks in 35 countries.

On September 30 1998, in the presence of representatives of UNESCO, the Italian Government, the Region of Sardinia and EMSA, the Declaration presented in Paris on July 30 was confirmed and the Carta di Cagliari (Charter of Cagliari) (UNESCO, 1998) signed. In the latter, the Government pledged to pass a law to establish the Park, however, two years later the law to formalize it had still not been approved. There followed protests that erupted on November 52000 with the occupation of the mining gallery Villamarina-Sella; it lasted 366 days and ended only in October 2001, when the Minister for the Environment, in agreement with the President of the Region of Sardinia, signed the law and the decree establishing the Park (Castelli \& Pintus, 2005, p. 31-35). The Park is a non-profit public body which acts under the supervision of the Ministries of Environment and Protection of Land and Sea, Economic Development, University and Research, Culture and Heritage, the Autonomous Region of Sardinia, the provinces and municipalities included in the Community of the Park and the Universities of Cagliari and Sassari. Eight zones were destined to become part of the Park, with a very extensive total area of approximately 3,500 square kilometres, involving various municipalities. The localities, chosen based on geomineral, archaeological and natural values are as follows: (1) Monte Arci, (2) Orani, Guzzurra, Sos Enattos, (3) Funtana Raminosa, (4) Argentiera, Nurra, Gallura, (5) Sarrabus, 
Gerrei, (6) Arburese, Guspinese, (7) Iglesiente, (8) Sulcis. In the panorama of national parks it represents an atypical case given the discontinuity of the areas included in its perimeter and the presence of mineral deposits in so many different zones of Sardinia (Figure 3).

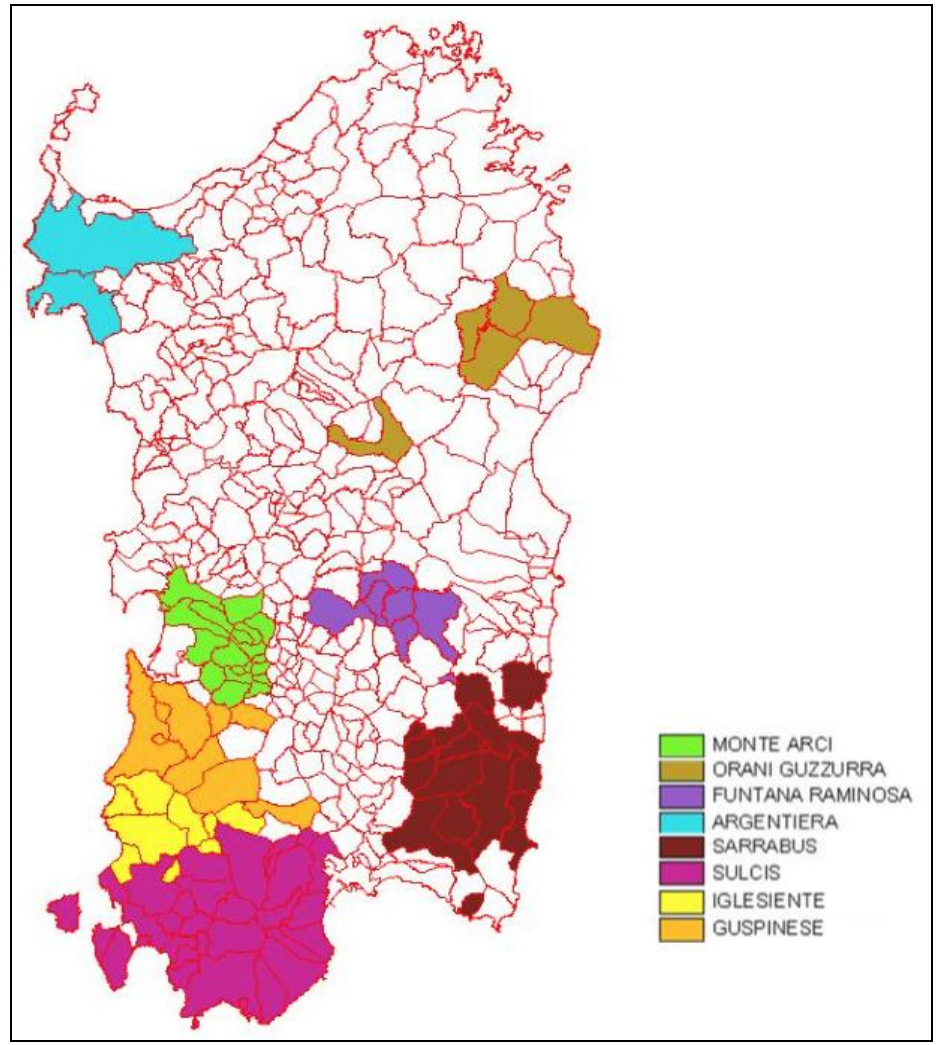

Figure 3. Map of the Geological and Mining Park of Sardinia (Source: CRENoS - Centre for North South Economic Research)

As reported in the socio-economic plan elaborated in 2008 by the Centro Ricerche Economiche Nord Sud (CRENoS - Centre for North South Economic Research), the study of the eight territories that form the Park made it possible to analyze a portfolio consisting of 383 various types of assets that were classified by the adoption of six functional macrocategories, diversified by type and geographic location: geomorphology and environmental, archaeology, civil archaeology, industrial archaeology, architecture and didactic-museum (CRENoS, 2008, p. 115-118). Those strictly related to the objective of our study are industrial archaeology, incorporating structures related to mining facilities, such as mines, washery (Figure 4), foundries, shafts and civil archaeology, which includes all the support buildings such as houses, guest quarters, surgeries etc. and didactic-museums.

CRENoS' first level of analysis showed that most of the studied properties belonged to the mining category, $57 \%$ in total, summing $10 \%$ for civil and $47 \%$ for industrial archaeology. Thus, in order to allow a perspective of study suited to a deeper analysis of the 383 surveyed assets, it was necessary to focus on a smaller sample. First of all, only those for which there were conceivable actions of enhancement by the Park were taken into consideration. This led to the identification of 65 sites accounting for approximately 
$20 \%$ of the assets initially estimated; subsequently, the sample of 65 was divided into five standard categories: abandonment, partial recovery, complete recovery, open to the public, industrial activity (CRENoS, 2008, p. 119-125).

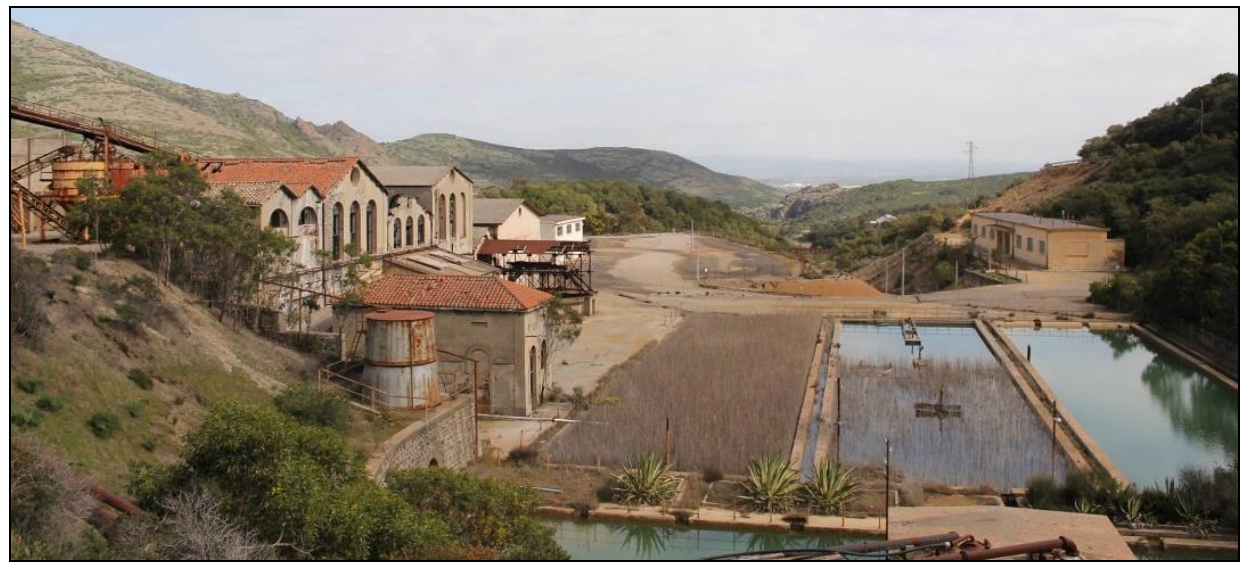

Figure 4. Principe Tomaso washery, Cantiere Piccalinna

\section{METHODOLOGY}

Among these categories, in this research paper we focus on the 'open to the public' category and, applying a further selection, we seek out sites that can be considered tourist products, that is, which rely on guided tours and a ticketing system. As is well known, in fact, tourism is a commercial activity whose goal is to earn, as reported by all marketing manuals (McKercher \& Du Cros, 2002). Given the absence of official documents with a comprehensive and detailed overview of the Park's assets since 2008, we visited the headquarters in Iglesias and interviewed the press officer to obtain up-to-date information. It was revealed that the Park Authority has no ownership whatsoever of any part of the territory, it does not directly manage any of the sites (apart from two nonprofit associations in Sulcis) and that almost all dismantled mining sites have been entrusted to Igea Spa, an in-house company of the Region of Sardinia, born as a legal entity operating in the area of security, environmental restoration and reclamation of mining areas abandoned or in the process of disposal. Given that the Park was found to lack comprehensive information and data regarding the open to the public category, these were to become the focus of this study. Therefore it became necessary to undertake an indepth investigation to record the evolution of those abandoned mining sites which have benefited from recovery works and subsequently been allocated to cultural/tourist use, and a desk and a field study within a comparative analysis were carried out.

As a starting point we chose the 2008 Socio-Economic Plan, as it is the latest official document available with exhaustive and complete data. Subsequently, we chose to use the webpage of the Park (www.parcogeominerario.eu) as a reference source to allow a comparative analysis with data reported in the 2008 Plan. Later a field analysis was carried out through telephone interviews and email enquiries to stakeholders of all the open to the public assets. Since in some case we received no answer to phone calls or emails, it was necessary to organize site inspections to those places. Furthermore, in order to verify the reliability of the information collected for the other sites, visits were organised at random. The assets visited were Pau's Museo dell'ossidiana museum, Miniera di Funtana Raminosa mine in Gadoni, Miniera dell'Argentiera mine in Sassari, 
mining route of Montevecchio in Guspini (Palazzo della Direzione, Cantiere Piccalinna, Cantiere Sant'Antonio and officine/workshops), Galleria Porto Flavia gallery in Iglesias, Centro Italiano della Cultura del Carbone (CCIC - The Italian Centre for Coal Mining Culture) in Carbonia and the mining district of Miniera di Rosas in Narcao.

In this phase we also investigated number of visitors per year, amount of human resources occupied, methods of management and financing.

\section{ANALYSIS AND OUTCOMES}

\section{Desk Analysis}

Taking into account only the sites used for tourism and museum activities which provide a ticketing system, we could identify in the Plan thirteen assets in eight municipalities, as shown in the summary table below (Table 1):

Table 1. Assets open to the public used for tourism up to September 2008

(Data source: Socio-economic Plan, CRENOS 2008)

\begin{tabular}{|l|l|l|}
\hline \multicolumn{1}{|c|}{ AREA } & MUNICIPALITY & \multicolumn{1}{c|}{ ASSET } \\
\hline Monte Arci & Pau & Percorso museale dell'ossidiana \\
\hline Funtana Raminosa & Gadoni & Miniera di Funtana Raminosa \\
\hline Sarrabus-Gerrei & Villasalto & Borgo minerario Villasalto \\
\hline \multirow{4}{*}{ Arbus-Guspini } & \multirow{3}{*}{ Guspini } & Palazzina della Direzione - Miniera di Montevecchio \\
\cline { 2 - 3 } & & Cantiere Piccalinna - Miniera di Montevecchio \\
\cline { 2 - 3 } & Arbus & Galleria Anglosarda - Miniera di Montevecchio \\
\hline \multirow{4}{*}{ Iglesiente } & \multirow{3}{*}{ Iglesias } & Pozzo Gal - Miniera di Ingurtosu \\
\cline { 2 - 3 } & & Galleria Porto Flavia - Masua \\
\cline { 2 - 3 } & & Grotta Santa Barbara - San Giovanni \\
\cline { 2 - 3 } & Buggerru & Guseo delle Macchine da Miniera \\
\hline Sulcis & Carbonia & Miniera di Serbariu -CCIC \\
\hline \multicolumn{2}{|c|}{ Tot. 13 assets in } \\
\hline
\end{tabular}

Then we compared these data with the Park's official webpage, which provides general, historical and institutional information and at the same time dedicates a single space to each of the eight areas of the Park divided into six topics: mining sites, cultural sites, trails, geological sites, natural sites and the part for booking a visit. The majority of these sections are under construction and lack content, the only one complete for all eight areas is the mining sites. After examining the information contained on this website for each area, we were able to build the following picture: of 377 municipalities in Sardinia, 81 are reported to be in the Park, 27 of them host 58 assets; 22 of these can be placed in the territory of 14 municipalities (Pau, Masullas, Lula, Gadoni, Guspini, Arbus, Gonnosfanadiga, Iglesias, Buggerru, Domusnovas, Fluminimaggiore, Carbonia, Narcao, Carloforte) and are officially presented as visitable, i.e. open to the public. The table below summarizes the information offered by the website as follows: area, total number of assets in that area, municipalities mentioned, number and name of only those offered as visitable, according to official sources of the Park (Table 2). Taking into account the visitable assets in this latest table (Table 2), built on data according to the official website and updated to December 2017 and comparing them with those in the previous one (Table 1) created on data presented in the Park's Socio-Economic Plan of 2008, the following differences were detected in terms of new openings or the absence of museums/sites. New openings in Areas 
1 and 2 are detected: the GeoMuseo museum of Masullas and the mining asset Miniera di Sos Enattos in Lula; the mining village Miniera di Villasalto in Area 5 is still mentioned but as non-visitable, while in the Plan it was among the open sites. In the Iglesiente area we notice four new assets: Museo del Minatore of Genna Luas (Iglesias) and Museo del Minatore of the Malfidano mine (Buggerru), also the Miniera di Antas mine (Fluminimaggiore) and the mine Miniera di Perda Niedda (Domusnovas).

Table 2. Assets open to the public used for tourism up to December 2017

(Source: Authors' elaboration of data from the Park's official website)

\begin{tabular}{|c|c|c|c|c|}
\hline & $\begin{array}{c}\text { ASSETS IN } \\
\text { THE WEBSITE }\end{array}$ & $\begin{array}{l}\text { MUNICIPALITIES } \\
\text { MENTIONED }\end{array}$ & VISITABLE & $\begin{array}{c}\text { VISITABLE ASSETS' } \\
\text { NAME }\end{array}$ \\
\hline \multirow[t]{2}{*}{ Monte Arci } & \multirow{2}{*}{4} & Pau & 1 & Museo dell'ossidiana \\
\hline & & Masullas & 1 & GeoMuseo Monte Arci \\
\hline \multirow{2}{*}{\begin{tabular}{|c|} 
Orani, Guzzurra, \\
Sos Enattos \\
\end{tabular}} & \multirow[t]{2}{*}{4} & Orani & - & - \\
\hline & & Lula & 1 & Miniera di Sos Enattos \\
\hline \multirow{2}{*}{\begin{tabular}{|l|} 
Funtana \\
Raminosa \\
\end{tabular}} & \multirow[t]{2}{*}{2} & Gadoni & 1 & Miniera di Funtana Raminosa \\
\hline & & Seui & - & - \\
\hline \multirow{2}{*}{$\begin{array}{l}\text { Argentiera } \\
\text { Nurra Gallura } \\
\end{array}$} & \multirow[t]{2}{*}{2} & Sassari & - & - \\
\hline & & La Maddalena & - & - \\
\hline \multirow{4}{*}{$\begin{array}{l}\text { Sarrabus } \\
\text { Gerrei }\end{array}$} & \multirow{4}{*}{4} & Masullas & - & - \\
\hline & & Villasalto & - & - \\
\hline & & Villaputzu & - & - \\
\hline & & San Vito & - & - \\
\hline \multirow[t]{4}{*}{$\begin{array}{l}\text { Arburese } \\
\text { Guspinese }\end{array}$} & \multirow[t]{4}{*}{9} & Guspini-Montevecchio & 2 & $\begin{array}{l}\text { Galleria Anglosarda, Palazzo } \\
\text { della Direzione }\end{array}$ \\
\hline & & $\begin{array}{l}\text { Arbus-Montevecchio e } \\
\text { Ingurtosu }\end{array}$ & 3 & $\begin{array}{l}\text { Museo Multimediale, Pozzo } \\
\text { Amsicora, Musei di Montevecchio }\end{array}$ \\
\hline & & Gonnosfanadiga & 1 & Perd'e Pibera \\
\hline & & Villacidro & - & - \\
\hline \multirow{9}{*}{ Iglesiente } & \multirow[t]{9}{*}{25} & \multirow[t]{4}{*}{ Iglesias } & \multirow{4}{*}{5} & Galleria Porto Flavia \\
\hline & & & & $\begin{array}{l}\text { Galleria Villamarina } \\
\text { Grotta di Santa Barbara }\end{array}$ \\
\hline & & & & $\begin{array}{l}\text { Museo delle Macchine di } \\
\text { Masua }\end{array}$ \\
\hline & & & & $\begin{array}{l}\text { Museo del Minatore di Genna } \\
\text { Luas }\end{array}$ \\
\hline & & \multirow[t]{2}{*}{ Buggerru } & \multirow{2}{*}{2} & Galleria Henry \\
\hline & & & & Museo del Minatore di Buggerru \\
\hline & & Domusnovas & 1 & Miniera di Perda Niedda \\
\hline & & Fluminimaggiore & 1 & Miniera di Antas \\
\hline & & Gonnesa & - & - \\
\hline \multirow[t]{7}{*}{ Sulcis } & 8 & Carbonia & 1 & CICC - Museo del Carbone \\
\hline & & Narcao & 1 & Miniera di Rosas \\
\hline & & Carloforte & 1 & Museo di Capo Becco \\
\hline & & Nuxis & - & - \\
\hline & & Villamassargia & - & - \\
\hline & & Assemini e Capoterra & - & - \\
\hline & 58 & 27 & 22 & \\
\hline
\end{tabular}

Two new sites also appear in the area of Sulcis: the mining district of Miniera di Rosas in the Municipality of Narcao and the museum Museo di Capo Becco in Carloforte. Special attention has to be dedicated to the zone Arbus-Guspini, where the mining site of 
Perd'e Pibera is offered as new open asset in the Municipality of Gonnosfanadiga, whilst the assets located in the Municipalities of Guspini and Arbus are grouped and presented in two different ways on the website and in the Plan.

Outcomes after desk analysis show a growth of nine visitable assets involving a further six municipalities from 2008 to 2017. At this stage it was not possible to make a comparison with regard to human resources, annual inputs or methods of management and financing as these data exist only in the Plan but not on the website.

\section{FIELD ANALYSIS}

As already mentioned, in the field analysis we carried out investigation into the open to the public sites through phone interviews and email enquiries, together with site inspections and direct interviews with the aim of determining the number of visitors per year, amount of human resources occupied, methods of management and financing.

As a result we obtained an insight into the current state of the Park, i.e. which museums dedicated to the mines' culture or geology and which mining assets rehabilitated and turned into a cultural tourism product following the closure of mines are presently accessible to the public with a guide and ticketing system and which, despite having been opened since the institution of the Park are at the moment closed. We discovered that some assets, while presented as visitable on the website, cannot be referred to as a tourist product, as they are in a state of disrepair/neglect or are unmanaged, or are administered by volunteers in a discontinuous manner. The outcome is reported in the following table (Table 3). On reviewing data obtained after inspecting the website and in light of the field analysis results, we confirmed that the GeoMuseo Masullas museum, the Miniera di Antas mine in Fluminimaggiore and the Miniera di Rosas mine in Narcao are new visitable assets, whilst all the others, for various reasons are not. The Miniera di Sos Enattos in Lula was open in 2010 but closed in 2014; Minera di Funtana Raminosa, Musei di Montevecchio, Galleria Anglosarda, Museo delle macchine da miniera of Masua are all closed. The Museo del Minatore of Genna Luas is managed by volunteers with free entry; the Museo del Minatore of Buggerru is rarely open and failed to supply any information about visits per year, human resources or other. In Miniera di Perda Niedda in Domusnovas a recovery was implemented and some miners' houses were transformed into an agriturismo, housing a small museum dedicated to the mine, this can be visited for free and on demand. In the Miniera di Perd'e Pibera in Gonnosfanadiga, the recovered assets are destined for other uses. Finally, there is no trace of the existence of Museo di Capo Becco in Carloforte.

Table 3. Open assets/products in the Park

\begin{tabular}{|c|c|c|c|c|c|}
\hline AREA & $\begin{array}{c}\text { COMMON } \\
\text { ASSETS } \\
\text { /PRODUCTS }\end{array}$ & $\begin{array}{c}\text { NEW } \\
\text { ASSETS/PROD } \\
\text { UCTS (WEB } \\
\text { AND FIELD) }\end{array}$ & $\begin{array}{c}\text { ASSETS/ } \\
\text { PRODUCTS IN } \\
\text { THE PLAN BUT } \\
\text { NOT IN THE } \\
\text { WEBSITE }\end{array}$ & \begin{tabular}{|c|} 
NEW \\
RESOURCES IN \\
THE WEB \\
- NOT A \\
PRODUCT
\end{tabular} & \begin{tabular}{|c|} 
TOTAL PERAREA- \\
EXCLUDING \\
RESOURCES THAT \\
ARE NOT A PRODUC \\
AND CLOSE ONES
\end{tabular} \\
\hline Monte Arci & $\begin{array}{c}\text { Museo } \\
\text { dell'ossidiana }\end{array}$ & $\begin{array}{l}\text { GeoMuseo } \\
\text { Masullas }\end{array}$ & & & $\begin{array}{c}\text { Museo dell'ossidiana, } \\
\text { Geomuseo Masullas }\end{array}$ \\
\hline $\begin{array}{c}\text { Orani, } \\
\text { Guzzurra, } \\
\text { Sos Enattos }\end{array}$ & & $\begin{array}{l}\text { Miniera di Sos } \\
\text { Enattos }\end{array}$ & & & - \\
\hline $\begin{array}{c}\text { Funtana } \\
\text { Raminosa }\end{array}$ & $\begin{array}{c}\text { Miniera di } \\
\text { Funtana Raminosa }\end{array}$ & & & & - \\
\hline $\begin{array}{c}\text { Sarrabus } \\
\text { /Gerrei }\end{array}$ & & & $\begin{array}{l}\text { Museo Su } \\
\text { Suergiu }\end{array}$ & & $\begin{array}{c}\text { Museo Su } \\
\text { Suergiu }\end{array}$ \\
\hline
\end{tabular}


Adriana Mossa,

José Antonio Camúñez-Ruiz, Francesco Morandi

\begin{tabular}{|c|c|c|c|c|c|}
\hline \multirow{6}{*}{$\begin{array}{l}\text { Arburese } \\
\text { Guspinese }\end{array}$} & \multirow{3}{*}{$\begin{array}{c}\text { Palazzo della } \\
\text { Direzione }\end{array}$} & Cantiere & \multirow{3}{*}{$\begin{array}{c}\text { Cantiere } \\
\text { Piccalinna }\end{array}$} & \multirow{6}{*}{$\begin{array}{l}\text { Miniera di } \\
\text { Perd'e } \\
\text { Pibera }\end{array}$} & \multirow{6}{*}{$\begin{array}{c}\text { Palazzo della } \\
\text { Direzione, } \\
\text { Cantiere } \\
\text { Piccalinna, } \\
\text { Cantiere } \\
\text { Sant’Antonio, } \\
\text { officine, Pozzo } \\
\text { Gal, Museo } \\
\text { Multimediale, } \\
\text { Pozzo Amsicora }\end{array}$} \\
\hline & & & & & \\
\hline & & Officine & & & \\
\hline & Pozzo Gal & $\begin{array}{c}\text { Museo } \\
\text { Multimediale }\end{array}$ & & & \\
\hline & $\begin{array}{c}\text { Galleria } \\
\text { Anglosarda }\end{array}$ & $\begin{array}{c}\text { Musei } \\
\text { Montevecchio }\end{array}$ & & & \\
\hline & & Pozzo Amsicora & & & \\
\hline \multirow{5}{*}{ Iglesiente } & $\begin{array}{c}\text { Galleria Porto } \\
\text { Flavia }\end{array}$ & $\begin{array}{l}\text { Miniera di } \\
\text { Antas }\end{array}$ & & $\begin{array}{c}\text { Museo del } \\
\text { Minatore di } \\
\text { Genna Luas }\end{array}$ & \multirow{5}{*}{$\begin{array}{c}\text { Galleria Porto } \\
\text { Flavia, Galleria } \\
\text { Villamarina, } \\
\text { Grotta Santa } \\
\text { Barbara, Galleria } \\
\text { Henry, Miniera } \\
\text { di Antas }\end{array}$} \\
\hline & $\begin{array}{c}\text { Galleria } \\
\text { Villamarina }\end{array}$ & $\begin{array}{l}\text { Museo del } \\
\text { minatore } \\
\text { Buggerru }\end{array}$ & & $\begin{array}{l}\text { Miniera di } \\
\text { Perda } \\
\text { Niedda }\end{array}$ & \\
\hline & $\begin{array}{c}\text { Grotta Santa } \\
\text { Barbara }\end{array}$ & & & & \\
\hline & $\begin{array}{l}\text { Museo macchine } \\
\text { da miniera Masua }\end{array}$ & & & & \\
\hline & $\begin{array}{c}\text { Galleria } \\
\text { Henry }\end{array}$ & & & & \\
\hline Sulcis & $\begin{array}{c}\text { Miniera di } \\
\text { Serbariu/CICC }\end{array}$ & $\begin{array}{l}\text { Miniera di } \\
\text { Rosas }\end{array}$ & & $\begin{array}{c}\text { Museo di } \\
\text { Capo Becco }\end{array}$ & $\begin{array}{l}\text { CICC, Miniera di } \\
\text { Rosas }\end{array}$ \\
\hline
\end{tabular}

As shown in the table 3 above, the findings of the field analysis research led us to affirm that there are currently 17 open sites (between museums and sites/mining villages) managed by companies with guided tours and a ticketing system, in the territory of 10 municipalities. Some assets that were in the Plan as open to the public but not present on the website, are currently open such as: Cantiere Piccalinna and Museo Su Suergiu of Villasalto. It is necessary to specify that both in the Plan and on the website the mine of Su Suergiu is mentioned, however the mine is not visitable whilst the open resource is the museum dedicated to miners - Museo Su Suergiu - set in the management building of the mine of Su Suergiu. Regarding Area 4 - Argentiera, Nurra, Gallura - their assets do not appear in the tables because in both the Plan and Park's website, the Miniera dell'Argentiera in Sassari and the cave of Cala Francese on the island of La Maddalena have never been presented as open to the public/visitable, a condition confirmed by field analysis. In Argentiera, recovery works were carried out at the washery and Pozzo Podestà, but these can only be visited once a year and free of charge, during the event organized by the Municipality of Sassari Monumenti Aperti. Cala Francese, on the other hand, is on private land and it is possible for groups to visit it for free with advance booking. In some cases, restoration had been completed, but the facility plan for tourist-receptive purposes has never been implemented, such as at the Miniera di Orbai in Villamassargia or the Palazzo della Direzione of Ingurtosu, which remain closed (and therefore not included in the tables).

The Palazzo della Direzione of Canale Serci was renovated but used as offices of the Forestry Authority of Sardinia. The Palazzo Bellavista in the Monteponi mine was for a while a seat of the University of Cagliari and hosted the faculties of Material 
Science and IT, as well as the Master's Degree in Geographical Information Systems. It is important to mention Grotta San Giovanni in Domusnovas, in the Plan as a nonproduct as accessible for free, because in September 2017 the management of the cave, jointly with the Nuraghe s'Omu e s'Orcu was assigned to the Consortium Natura Viva ensuring a ticket office to regulate access to the cave, equipped with a train (trenino verde), that will travel 900 meters and will connect it to the Nuraghe and other attractions. There are also other places dedicated to mining heritage all over the island, but they cannot be referred to as products because they are open only thanks to the local community's pride in the millenary mining heritage of Sardinia.

These are managed by volunteers and provide free guided tours, and include Museo dell'Arte Mineraria in Iglesias, which was in the Plan, although not on the website. Also included is the Museo Mineralogico e Paleontologico inside the mining school of Iglesias, which houses an ancient collection of fossil minerals and rocks from Sardinia and other parts of the world and, unfortunately, can only be visited during the cultural manifestation Monumenti Aperti and a few other occasions, and the Miniera di Su Zurfuru in Fluminimaggiore. As stated above, our analysis focused also on number of visits per year, method of management and financing, human resources. The results obtained regarding visitors per year in 2016 report 112,312 entrances for 16 assets out of 17 (lack of numbers for Galleria Villamarina); we also calculated the average of visits in the last 5 years in order to allow a comparison with average number presented in the Plan: in 2008 the average was 62,201 for 13 assets in 2016 it was 90,949 for 17 assets, with a small growth of 28,748 . It is noteworthy that a shared detailed model for the registration of entries to sites does not exist, even if it represents a necessary tool for analyzing the composition of targeted demand and supply marketing strategies.

Only the CCIC uses such a model and reports the type of visitors (individual, school groups), provenance, educational qualification, age group, and means of communication. As regards human resources occupied, despite the increase in number of open sites, these still number 73 as in 2008, even though they may increase in high season. Outcomes concerning methods of management and financing, show that the sites' management model is totally fragmented, both with regard to financing conditions and legal composition. As already mentioned, the Park constitutes two non-profit associations, one with the Municipality of Carbonia - the Italian Centre for Coal Mining Culture (CCIC) and another with the Municipality of Narcao - Rosas Mining Association. The majority of the mines have been entrusted to Igea Spa, an in-house company of Region Sardinia. In recent years we are witnessing the passage of ownership of the assets from Igea to the municipalities. The ownership of the other sites can be attributed to municipalities and these are managed by cooperatives or cultural associations with municipal funds.

Table 4. Park status in 2017

\begin{tabular}{|c|c|c|c|c|c|c|}
\hline AREA & ASSETS & OWNERSHIP & MANAGEMENT & HR & $\begin{array}{l}\text { VISITS } \\
2016\end{array}$ & $\begin{array}{c}\text { AVERAGE } \\
\text { LAST 5 YEARS } \\
\text { (2012/2016) }\end{array}$ \\
\hline \multirow{2}{*}{$\begin{array}{l}\text { Monte } \\
\text { Arci }\end{array}$} & Museo dell’Ossidiana & $\begin{array}{c}\text { Municipality of } \\
\text { Pau }\end{array}$ & $\begin{array}{c}\text { Associazione } \\
\text { Culturale Menabo }\end{array}$ & 3 & 3.157 & 2.248 \\
\hline & Geomuseo Masullas & $\begin{array}{l}\text { Municipality of } \\
\text { Masullas }\end{array}$ & $\begin{array}{l}\text { Cooperativa Il } \\
\text { Chiostro }\end{array}$ & 5 & 2.394 & 1.925 \\
\hline $\begin{array}{c}\text { Sarrabus/ } \\
\text { Gerrei }\end{array}$ & $\begin{array}{c}\text { Museo archeologico } \\
\text { - minerario } \\
\text { dell'attività mineraria } \\
\text { Su Suergiu }\end{array}$ & $\begin{array}{l}\text { Municipality of } \\
\text { Villasalto }\end{array}$ & $\begin{array}{l}\text { Cooperativa } \\
\text { Agorà Sardegna }\end{array}$ & 3 & 200 & 200 \\
\hline
\end{tabular}


Adriana Mossa,

José Antonio Camúñez-Ruiz, Francesco Morandi

\begin{tabular}{|c|c|c|c|c|c|c|}
\hline $\begin{array}{l}\text { Arburese/ } \\
\text { Guspinese }\end{array}$ & $\begin{array}{c}\text { Miniera di } \\
\text { Montevecchio: } \\
\text { Palazzo della } \\
\text { Direzione, officine, } \\
\text { Cantiere Sant'Antonio, } \\
\text { Cantiere Piccalinna }\end{array}$ & $\begin{array}{l}\text { Municipality of } \\
\text { Guspini }\end{array}$ & $\begin{array}{l}\text { Società } \\
\text { Cooperativa } \\
\text { Lugori }\end{array}$ & 5 & 10.321 & 7.210 \\
\hline & $\begin{array}{c}\text { Miniera di Ingurtosu } \\
\text { e Montevecchio: } \\
\text { Pozzo Gal, Museo } \\
\text { Multimediale, Pozzo } \\
\text { Amsicora }\end{array}$ & $\begin{array}{l}\text { Municipality of } \\
\text { Arbus }\end{array}$ & $\begin{array}{c}\text { Ceas di Ingurtosu } \\
\text { Associazione } \\
\text { Zampa Verde }\end{array}$ & 5 & 5000 & 5.000 \\
\hline \multirow{5}{*}{ Iglesiente } & $\begin{array}{c}\text { Galleria Porto Flavia } \\
\text { - Masua }\end{array}$ & $\begin{array}{l}\text { Municipality of } \\
\text { Iglesias }\end{array}$ & $\begin{array}{l}\text { Municipality of } \\
\text { Iglesias }\end{array}$ & 10 & 24.611 & 16.584 \\
\hline & $\begin{array}{l}\text { Galleria Villamarina - } \\
\text { Monteponi }\end{array}$ & Igea & $\begin{array}{l}\text { Municipality of } \\
\text { Iglesias }\end{array}$ & 5 & - & 2.076 \\
\hline & Grotta Santa Barbara & Igea & $\begin{array}{l}\text { Municipality of } \\
\text { Iglesias }\end{array}$ & 8 & 4.256 & 4.694 \\
\hline & Galleria Henry & Igea & $\begin{array}{c}\text { Municipality of } \\
\text { Buggerru }\end{array}$ & 6 & 9.200 & 6.181 \\
\hline & Tempio di Antas & Start-uno & $\begin{array}{l}\text { Municipality of } \\
\text { Fluminimaggiore }\end{array}$ & 6 & 21.019 & 17.919 \\
\hline \multirow{2}{*}{ Sulcis } & $\begin{array}{c}\text { CCIC - Centro } \\
\text { Italiano della Cultura } \\
\text { del Carbone }\end{array}$ & $\begin{array}{l}\text { Italian Center of } \\
\text { Culture of Coal } \\
\text { (Municipality of } \\
\text { Carbonia and Park) }\end{array}$ & $\begin{array}{c}\text { Associazione } \\
\text { Centro Italiano } \\
\text { della Cultura del } \\
\text { Carbone } \\
\end{array}$ & 7 & 20.894 & 17.400 \\
\hline & Miniera di Rosas & $\begin{array}{c}\text { Rosas Mining } \\
\text { Association } \\
\text { (Municipality of } \\
\text { Narcao and Park) }\end{array}$ & $\begin{array}{c}\text { Associazione } \\
\text { Miniere di Rosas }\end{array}$ & 10 & 11.260 & 9.512 \\
\hline & & & & 73 & 112.312 & 90.949 \\
\hline
\end{tabular}

Regarding method of promotion, it has emerged that the Park website performs only an institutional role, it is static and written solely in Italian, none of the places presented in it are linkable and no information on opening hours and prices are provided. On the other hand we verified that each museum, mining site/village has its own webpage for promoting their resources. From our analysis it emerged that the best practice is represented by the CCIC - Italian Centre for Coal Mining Culture (Figure 5) in the Grande Miniera di Serbariu and the mining district of Miniera di Rosas (Figure 6).

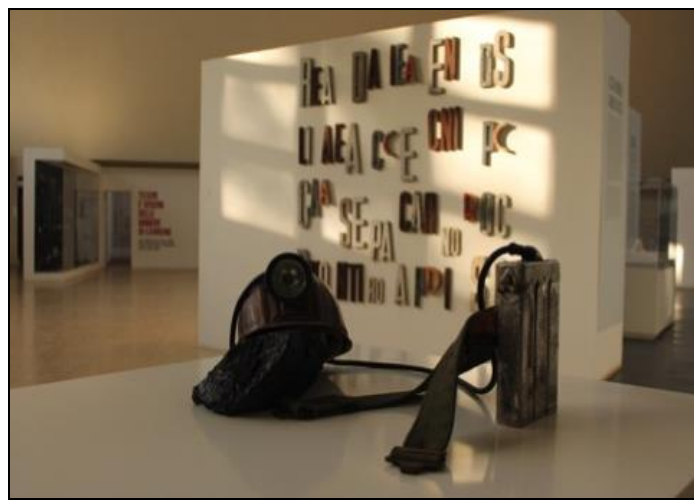

Figure 5. CCIC-The Italian Centre for Coal Mining Culture.

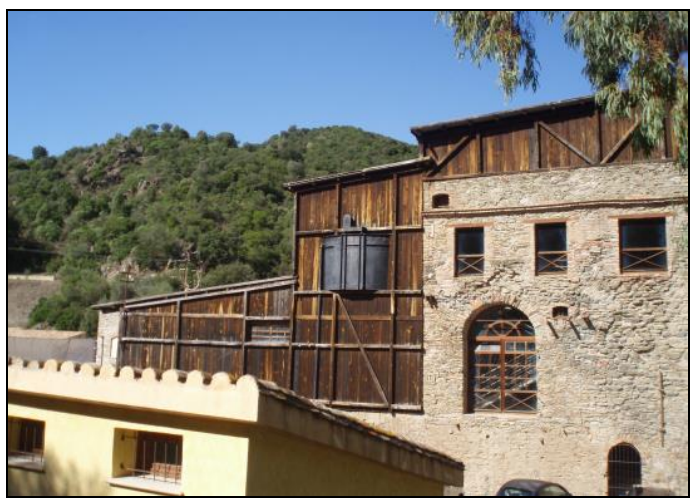

Figure 6. Mining district of Miniera di Rosa 
The CCIC is the site of the Park with more recognition, services and greater accuracy in collecting incoming data flows, whilst Rosas stands out for services offered, including accommodation facilities and catering and a winning economic model. Both of these are located in the Sulcis area and are open all year round, but above all they share the same management and financing method. Given the importance of these two places, we provide a more detailed description of them. The CICC arises in the former coal mine of Serbariu and belongs to the territory of the Municipality of Carbonia, a center that developed around the coal mining activity. The presence of coal in this area was noticed by General Lamarmora already in 1834, although the city was founded by the Fascist regime to host the workers occupied in the mine. The museum includes the lampstand, the underground gallery and the winch hall. In the museum there is also a bookshop, a cafe and a conference room with 130 seats and an audio-video system, the website is offered in five languages. It gained Tripadvisor Awards in 2014 and 2015 and it represents Italy in the European Network of Mining Museums, currently composed of seven European mining sites in Europe. It is also one of the anchor points of the ERIH (European Route of Industrial Heritage). The mine, which was active from 1937 to 1964, was transformed into a tourist resource and opened to the public on February 82006 following the establishment of CCIC by the Municipality of Carbonia and the Park.

The mining village of Rosas is located in the municipality of Narcao. This metallic field has been known since the nuraghic era and was exploited in both Roman and Pisan times. In 1851 it was granted by King Vittorio Emanuele II as the Società dell'unione miniere Sulcis e Serrabus for the extraction of galena. Among the extracted minerals we must mention rosasite, discovered in 1929 and named after the place where it was first found. Mining activities ceased definitively in 1980 (Sabiu, 2007) and the site faced a lengthy transformation resulting in the birth of an open-air museum, officially accessible from July 1 2009. The former miners' lodgings have been transformed into a split-site hotel, consisting of 19 houses and a hostel for a total of 110 beds, including a cafeteria, a restaurant and a picnic area. There are many events organized every year in the mine such as Pianeta Terra, Rosso in miniera, San Valentino in miniera, Capodanno in miniera, Festival di Santa Barbara and various shows in summertime. A recent study (Cannas, 2016) has dealt with the management project in place, concluding that "the organisational model that grew out of this project was based on a combination of public and private initiatives and remained true to its goal of creating conditions of development of a publicly owned asset using a private business model. This is known as an open economic model..." (Cannas, 2016, p. 54). This model identified by Cannas (2016) in Rosas is part of the more general concept according to which in order to transform a cultural heritage into a tourist resource, stakeholders need to work together and have a common goal (McKersher \& Du Cros, 2002). Therefore, we can state that an integrated and organized network between Region, Park and municipalities is desirable; an integrated and organized network between the public and private that shares one unique recognizable brand. Furthermore, a dynamic, multilingual and up-to-date website is still required. It may be taken for granted nowadays when demand is mostly placed on the net and it creates user-generated contents (Ejarque, 2015) but, due to the current state of the Park's website, we must highlight the importance of a tool which provides updated information about all activities and attractions of each area, including accomodation and restaurants and the possibility of booking them, where possible.

\section{CONCLUSIONS AND SUGGESTIONS}

Since the drafting of the Socio-Economic Plan until now, advancements in open sites have been registered. At the same time regressions have been recorded, because of the closure 
of pre-existing places. Taking into account the average, a small increase in visitors per year has been detected, and no growth in human resources occupied which remain unchanged. Heterogeneity in management has been noticed, as well as the lack of an integrated network and a consequent fragmentation of communication, all of which are factors that reduce the potential of the Park as an opportunity in the tourist market as a niche product. The best practices are represented by the Villaggio Minerario di Rosas and by the CCIC - Italian Centre for Coal Mining Culture. Hence, we suggest applying this model to all the resources of the Park (Cannas, 2016). The value of this research paper can be identified in the collection of information that has led to building an up-to-date picture of the Park with data that are unpublished. It can be a starting point for the stakeholders involved in decision-making processes at a regional level if they decide to invest in an incisive way in the Sardinian mining industrial tourism sector. As we believe has emerged in the course of this article, the retrieval of the data and information reported here has not been easy and is the result of lengthy investigation work and in some cases the desired collaboration on the part of the subjects involved was limited. The absence of a single and up-to-date database has constituted a huge limit for this research whose initial aim was a comparative analysis of analogous parks in the European panorama in order to identify best practices and create a tourist-cultural path that, starting from the mining industrial archaeology, would allow the visitor to discover small and medium enterprises operating in the vicinity of the Park, focusing on emotions and experience. The emotional component of tourism is, in fact, crucial (Villamira, 2001; Pini, 2016; Prayag et al., 2017) and heritage tourism raises emotions and creates new experiences, and as such is a real opportunity to exploit alongside not only seaside tourism, but also other sectors such as: food and wine, sports events, folklore, archaeology and architecture. Unfortunately, it was necessary to change the direction of our research and we had to focus on the recognition of basic data such as mapping open sites or annual inputs. We are at the moment working on a further level of research to reach our orginal goal.

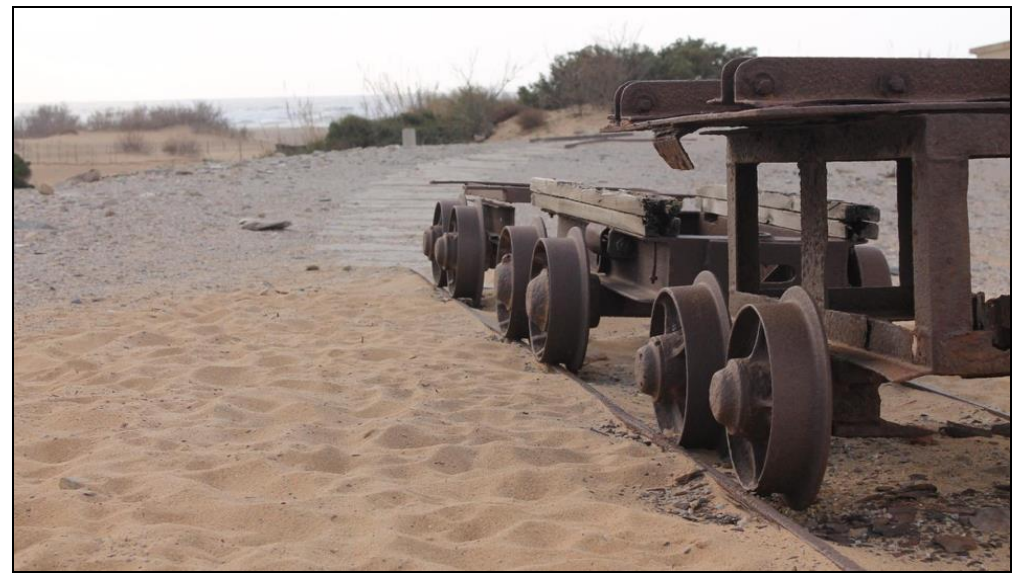

Figure 7. Narrow gauge train, Piscinas, Arbus

We conclude by reporting that cultural heritage tourism is an integral part of the Sardegna - isola della qualità della vita strategy (2014-2017), of the Tourism Department of the Sardinia Region, in which it occupies an absolute important place. Following the vision of the strategic plan for regional tourism, Sardinia - in balance with identity, traditions, culture and nature - is a place where the beauty of the landscape, environmental sustainability and cultural identity can make a territorial system unique and able to generate an optimal quality 
of life for the residents, attract new tourists and investors, generate jobs, re-integrate into the working circuit those who are temporarily excluded and ensure social well-being. The island where it is possible to have a holiday experience is oriented towards the definition of a new territorial product with a tourist vocation, to be positioned on the national market and on the international scenario, in which cultural tourism assumes a fundamental value. Hope for advancements can be found in the information appearing on the Park's website in December 2017. It states that in 2018 the Park, in synergy with the Region of Sardinia and the municipalities concerned, based on the approved Management Plan of October 2017 from the Community of the Park, is committed to carrying out improvements in Porto Flavia and Galleria Henry and re-opening Galleria Anglosarda, Miniera di Sos Enattos, Funtana Raminosa, as well as opening Miniera di Su Suergiu, Orbai and Argentiera.

\section{REFERENCES}

Battino, S. (2013). La imagen que perciben los turistas que visitan Cerdeña. Primeras consideraciones extraidas de una investigación realizada mediante cuestionarios (The image perceived by tourists who visit Sardinia. First considerations extracted from an investigation carried out through questionnaires). Cuadernos de Turismo. n. 32, p. 37-64.

Brigaglia, M. (2002). Cronache del secondo Novecento. Storia della Sardegna. 5: il Novecento (Chronicles of the late twentieth century. History of Sardinia. 5: the twentieth century), edited by Brigaglia, Manlio, Attilio Mastino, and Gian Giacomo Ortu, p. 38-65. Laterza. Roma.

Butler, R. W. (2011). Tourism Area Life Cycle. Goodfellow, Oxford.

Cannas, R. (2010). Politiche pubbliche per la stagionalità del turismo da una prospettiva territoriale. Casi di studio in Scozia $e$ in Sardegna (Public policies for the seasonality of tourism from a territorial perspective. Case studies in Scotland and Sardinia). PhD diss. Università di Bologna.

Cannas, R. (2016). The Sustainable Tourism Management of Cultural Heritage: the Case of the Rosas Mine in Sardinia. AlmaTourism Journal of Tourism. Culture and Territorial Development, n. 14, p. 38-59. https://doi.org/10.6092/issn.2036-5195/6331.

Carcassi, U., \& Mura, I. (2009). Sardegna e malaria: Un nuovo approccio a un antico malanno (Sardinia and malaria: A new approach to an ancient disease). Carlo Delfino. Sassari.

Cartei, G.F. (2007). Convenzione europea del paesaggio e governo del territorio (European Landscape Convention and Territory Government). Il Mulino. Bologna.

Castagna, M. (2008). In Sardegna tra mare e miniere: 22 giorni a piedi nel più spettacolare parco geominerario d'Italia (In Sardinia between sea and mines: 22 days on foot in the most spectacular geo-mining park in Italy). Terre di mezzo. Milano.

Castelli, P. M., \& Pintus, E. (2005). Storia della costruzione del Parco geominerario storico ed ambientale della Sardegna e ruolo dell'associazione onlus per il Parco Geominerario Storico ed Ambientale della Sardegna (History of the construction of the historical and environmental geominerary park of Sardinia and the role of the non-profit association for the Historical and Environmental Geomining Park of Sardinia). Iglesias. http://www.parcogeominerario.eu/images/archivio_documenti/documenti. consorzio /STORIA_2ODELLA_2OCOSTRUZIONE_2ODEL_2OPARCO_20GEOMINERARIO.pdf.

Chessa, O., \& Pinna, P. (2008). La riforma della regione speciale: dalla legge statutaria al nuovo statuto speciale (The reform of the special region: from the statutory law to the new special statute). Giappichelli. Torino.

Dettori, D. (2002). Raccontare il turismo: una rassegna bibliografica (Telling about tourism: a bibliographic review), in Modelli di turismo in Sardegna: tra sviluppo locale e processi di globalizzazione (in Models of tourism in Sardinia: between local development and globalization processes), edited by Antonietta Mazzette, p. 246-264. Franco Angeli. Milano.

Di Gregorio, F., Frongia, P., Piras, G., \& Forresu, R. (2014). Map of the natural and cultural heritage in the landscape of the carignano wine district of the Sucis region (SW Sardinia). GeoJournal of Tourism and Geosites. n. 1, vol. 13, p. 66-78. ISSN 2065-0817, E-ISSN 2065-1198.

Ejarque, J. (2015). Social media marketing per il turismo: Come costruire marketing 2.o e gestire la reputazione della destinazione (Social media marketing for tourism: How to build marketing 2.0 and manage the reputation of the destination). Hoepli. Milano.

Fadda, A. (2001). Sardegna: un mare di turismo (Sardinia: a sea of tourism). Carocci. Roma.

Fadda, A. F. (2003). Paesaggi minerari in Sardegna (Mining landscapes in Sardinia). Coedisar. Cagliari.

Farsani, N. T., Coelho, C., \& Costa, C. (2011). Geotourism and geoparks as novel strategies for socio-economic development in rural areas. International Journal of Tourist Research. n. 1, vol. 13, p. 68-81. https://doi.org/10.1002/jtr.80o.

Forleo, M. B., Giannelli, A., Giaccio, V., Palmieri, N., \& Mastronardi, L. (2017). Geosites and parks for the sustainable development of inner areas: the matese mountain (Italy). GeoJournal of Tourism and Geosites. n. 2, vol. 20, p. 231-242. ISSN 2065-0817, E-ISSN 2065-1198. 
Adriana Mossa,

José Antonio Camúñez-Ruiz, Francesco Morandi

Gherardini, G. (1991). Statuto speciale e ordinamento della regione Sardegna (Special statute and organization of the Sardinia region). Esselibri-Simone. Napoli.

Hospers, G. J. (2003). Localization in Europe's Periphery: Tourism Development in Sardinia. European Planning Studies. n. 11, vol. 6, p. 629-645. doi: 10.1080/0965431032000108369.

Lavazza, S. (2008). Miniere al sole (Mines in the sun). $A M \& D$. Cagliari.

Mezzolani, S., \& Simoncini, A. (2001). Sardegna da salvare: storia, paesaggi, architetture delle miniere. Il Parco Geominerario della Sardegna (Sardinia to save: history, landscapes, architecture of the mines. The Geominerary Park of Sardinia). Archivio fotografico sardo. Nuoro.

McKercher, B., \& Du Cros, H. (2002). Cultural Tourism: The Partnership Between Tourism and Cultural Heritage Management. Haworth Press. New York.

Olita, O. (2007). Il Parco immaginato dai giovani, in 57 tesi di laurea le idee per dare vita al Parco Geominerario Storico e Ambientale della Sardegna (The Park imagined by young people, in 57 theses the ideas to give life to the Historical and Environmental Geo-mining Park of Sardinia). AM\&D. Cagliari.

Pini, G. (2016). Il marketing territoriale dell'Italia che non ti aspetti (The territorial marketing of Italy that you do not expect). Franco Angeli. Milano.

Poch, J., \& Llordés, J. P. (2011). The Basque coast Geopark: support for good practices in Geotourism. GeoJournal of Tourism and Geosites. n. 2, vol. 8, p. 272-280. ISSN 2065-0817, E-ISSN 2065-1198.

Prayag, G., Hosany, S., Muskat, B., \& Del Chiappa, G. (2017). Understanding the relationships between tourists' emotional experiences, perceived overall image, satisfaction, and intention to recommend. Journal of Travel Research. n. 1, vol. 56, p. 41-54. doi:http://dx.doi.org/10.1177/0047287515620567.

Roggio, S. (2012). Costa Smeralda: un luogo, un evento, un paradigma (Costa Smeralda: a place, an event, a paradigm), in Modelli di turismo in Sardegna: tra sviluppo locale e processi di globalizzazione (in Models of tourism in Sardinia: between local development and globalization processes), ed. by Antonietta Mazzette, p. 224-245, Franco Angeli. Milano.

Ruju, S. (2014). La Sardegna e il turismo: sei testimoni raccontano l'industria delle vacanze (Sardinia and tourism: six witnesses tell the holiday industry). Editrice Democratica Sarda. Sassari.

Sabiu, S. (2007). Rosas. Una miniera nella Sardegna contemporanea (Rosas. A minein contemporary Sardinia). AM\&D. Cagliari.

Tognotti, E. (2008). Per una storia della malaria in Italia: Il caso della Sardegna (For a history of malaria in Italy: The case of Sardinia). Franco Angeli. Milano.

Villamira, M. A. (2001). Psicologia del viaggio e del turismo (Psychology of travel and tourism). UTET. Torino.

Yolal, M. (2012). Geotourism and Geoparks: The Case of Kizilcahamam-Camlidere Geopark. GeoJournal of Tourism and Geosites. n. 2, vol. 10, p. 193-203. ISSN 2065-0817, E-ISSN 2065-1198.

*** Associazione Minatori e Memorie (Miners and Memories Association), (2008). Sardegna: minatori e memorie (Sardinia: miners and memories). A.MI.Me. Iglesias.

*** Centro Studi Mezzogiorno (South Study Center), (2016). Il Turismo in Sardegna, quali tematismi per un turismo destagionalizzato (Tourism in Sardinia, which themes for a seasonally adjusted tourism). SRM. Napoli. http://www.sr-m.it/wp-content/uploads/2016/10/Tematismi.pdf.

*** CRENoS (Centre for North South Economic Research), (2008). Piano economico-sociale del Parco Geominerario Storico e Ambientale della Sardegna (Economic and social plan of the Historical and Environmental Geomining Park of Sardinia). Centro Ricerche Economiche Nord Sud, Università degli Studi di Cagliari e Sassari. Cagliari.

**** CRENoS. (2017). Economia della Sardegna. $24^{\circ}$ Rapporto 2017 (Economy of Sardinia. 24th Report 2017). CUEC. Cagliari.

*** Federculture. (2017). $13^{\circ}$ Rapporto annuale Federculture 2017 (13th Annual Report of Federculture 2017). Gangemi. Roma.

****UNESCO. (1998). Carta di Cagliari(Chart of Cagliari). Cagliari. /documenti_consorzio/carta_di_cagliari.pdf http://www.parcogeominerario.eu/images/archivio_documenti.

*** Unioncamere and Fondazione Symbola (Italian Union of Chambers of Commerce and Symbola Foundation). (2016). Io sono Cultura: Rapporto 2016 (I am Culture: 2016 Report). /assets/files/Io\%20sono\%20cultura\%20 COMPLETA\%20210715_1437473737, pdf. http://www.symbola.net.

http://www.parcogeominerario.eu, accesed 15/12/2017.

http://www.globalgeopark.org/aboutGGN/list/index.htm, accesed 13/12/2017.

https://www.sardegnaturismo.it, accesed 16/12/2017.

http://www.sardegnacultura.it, accesed 14/12/2017.

http://www.minieredisardegna.it1 accesed 9/12/2017.

http://www.museossidiana.it, accesed 11/12/2017

http://www.geomuseomontearci.it/index.php, accesed 18/12/2017

http://www.igeaspa.it/it/homepage.wp, accesed 19/12/2017.

http://www.minieredisardegna.it/LeMiniere.php?IdM=35\&IdCM=\&SID=a82aab55e17e05a4azad776ege812fgb, accesed 12/12/2017.

http://www.minieradimontevecchio.it, accesed 13/12/2017.

http://www.ceasingurtosu.it, accesed 15/12/2017.

http://www.comune.iglesias.ca.it/it/tematiche/turismo/porto-flavia-masua/index.html

$\mathrm{http}: / /$ www.regione.sardegna.it/j/v/25? $\mathrm{s}=338133 \& \mathrm{v}=2 \& \mathrm{c}=3692 \& \mathrm{t}=1$ SIRED, (2017), Turismo, 2,9 milioni di arrivi nel 2016.

Submitted:

25.01.2018
Revised:

18.05.2018
Accepted and published online 22.05.2018 